\title{
AIM's Accountability in Financial Sustainability: The Role of Market Orientation
}

\author{
Soheil Kazemian, R. Abdul Rahman, Z. Ibrahim, and A. Abideen Adeymi
}

\begin{abstract}
The paper aims at providing insights into how three dimensions of market orientation namely; customer orientation, competitor orientation and inter-function coordination affect the financial performance of Amanah Ikhtiar Malaysia (AIM) as the oldest microfinance institution in South East Asia. Using a cross sectional survey, Partial Least Squares (PLS) as a variance-based structural equation modeling (SEM), the current study examines the AIM's accountability on market orientation in financial sustainability. The results provided empirical evidences that indicate customer orientation and inter-function coordination significantly affect financial performance of AIM. Nevertheless, competitor orientation has a negative and insignificant effect on sustainable financial performance of AIM. The result of the paper enhanced further the literature in understanding the long-term sustainable financial performance-based market orientation.
\end{abstract}

Index Terms-Accountability, market orientation, customer orientation, competitor orientation, inter-function coordination, sustainable financial performance.

\section{INTRODUCTION}

Most of the developing countries are living below the poverty line. In response to the need by the international community to design a comprehensive and full-supportive financial package for helping the poor, Muhammad Yunus developed the Grameen Bank model (microcredit and microfinance that provides small loans to poor entrepreneurs) in Bangladesh, in 1976 [1]. The Grameen Bank model has flourished in the past four decades all over the world. Likewise, in Malaysia, the Amanah Ikhtiar Malaysia (AIM) was established in September 1987, using the Grameen Bank model with some modifications. AIM as the oldest and one of the largest Grameen Bank replications in Asia, plays a very significant role in reducing poverty in Malaysia [2].

Although microfinance business is a growing market in Malaysia, still one of the most important issues of Malaysian microfinance institutions (MFIs) is their level of un-sustainability which will lead to lack of outreach and increasing poverty level. Microfinance providers in Malaysia are mostly not able to manage themselves financially and are dependent on governmental grants [3]. It could be the reason

Manuscript received October 14, 2013; revised December 9, 2013.

Soheil Kazemian, Rashidah Abdul Rahman, and Zuraeda Ibarahim are with the Accounting Research Institute (ARI), Universiti Teknologi Mara(UiTM), Shah Alam, Selangor, Malaysia (e-mail: Soheil.kazemian@yahoo.com, shidah@salam.uitm.edu.my, zuraeda_ibrahim@yahoo.co.uk).

Adewale Abideen Adeymi is with the Accounting Research Institute (ARI), International Islamic University Malaysia (IIUM), Gombak, Selangor, Malaysia (e-mail: abidewale@iium.edu.my). for the low number of microfinance providers despite of the high demand for microfinance services.

Consequently, it's vital for MFIs to sustain their current clients and attract more new ones as their financial and social resources to reach sustainability. So, in order to achieving this goal, MFIs need to follow a valid and reliable plan which contains guidelines in; attracting and saving clients, taking proper decisions in confrontation to competitors and finally taking proper internal interaction, enhancing the organization in the market.

Ref. [4] on page 6, defines market orientation as; "Market orientation is the organization wide generation of market intelligence pertaining to current and future customer needs, dissemination of the intelligence across departments, and organization wide responsiveness to it." This concept on the importance of sustaining and attracting customers, totally focuses on its three dimensions, namely customer orientation, competitor orientation and inter-function coordination, which are constructed from three major factors that include intelligence generation, intelligence dissemination and responsiveness [4].

In general, this study aims to address one gap in "sustainable performance-based market orientation research" in microfinance business; clarifying whether the nature of market orientation can impress the financial sustainability of MFIs or otherwise. The current study also tries to apply concept financial sustainability at the micro level organization in microfinance business. Specifically, the current study investigates the influence of market orientation on accountability in sustainable financial performance of AIM, as the oldest microfinance provider in Malaysia, to clarify how accountability in financial sustainability of AIM is affected by each three dimension of market orientation. Further, two control variables namely sustainability of customers and employees are used to determine the relationship between independent and dependent variables.

\section{BACKGROUND OF STUDY}

Amanah Ikhtiar Malaysia (AIM), which was established in September 1987 as a non-governmental organisation (NGO), resulted from an action research project carried out by the Centre for Policy Research of University Science Malaysia (USM), sponsored by the Asia and Pacific Development Centre (APDC), Islamic Economic Development Foundation of Malaysia (YPEIM) and the Selangor State Government called the Ikhtiar Project. The Ikhtiar Project was established in 1986 as a programme to eradicate poverty for the rural poor in Malaysia, with some modifications of the Grameen Bank model [5]. Amanah Ikhtiar, as the oldest and one of the 
largest Grameen Bank replications in Asia, plays a remarkable role in fighting poverty in Malaysia. The main objective of AIM is giving out small loans (on average, each loan is around RM3,000 (USD990), depending on the client's repayment ability, it could be more or less) to poor households for financing their income generating activities, and, in fact, helping them to move out from the poverty group [2].

The recipients (Shabbat) have to repay loans on a weekly payment basis and once the current loan is fully repaid, larger loans will be offered. The loans given are normally restricted to between RM1,000 (USD330) and RM4,000 (USD1,330). Successful clients (borrowers) can increase the amount of loans applied for up to RM10,000 (USD3,300). It is complementary to the Government's objective to eradicate poverty amongst the poor households in Malaysia. AIM targets poor women's households whose income is less than $66 \%$ of the poverty line stated by the government (for 2012 , the client's income should be less than RM2,300) [5]. AIM has a good collection rate - more than $95 \%$ in all branches. This is quite remarkable when compared to that of banks that provide microfinance services, which is about $70 \%$. AIM has 144 active branches in all 12 states of Malaysia, at present. These branches could be divided based on the number of sahabat (clients) into two categories; more than 5000 sahabats and less than 5000 sahabats.

Furthermore, according to [6], AIM is considered an Islamic organization because its operation loan system is shariah compliant (they charge only $10 \%$ as administrative charges for covering current expenses) and in addition AIM provides Islamic financial services like "Tawarruq"(involves buying an item on credit and selling the item on spot to get cash) and "Qard-al-Hassan"(an interest free loan that is typically made to the needy).

\section{LITERATURE REVIEW AND HYPOTHESES DEVELOPMENT}

Based on previous literature, market orientation is appeared as an important factor in leading organizations to the main objectives of accountability (superior long-term social and financial performance) [7]. Market oriented firms are likely to achieve long-term profit by providing superior value to the customers by identifying their current and future needs, knowing the strengths and plans of competitors, showing coordinated and just in time reactions and presenting new services in order to affect the market environment [8]. Several studies have been conducted, providing evidence as the positive effects of market orientated organizations in providing superior long-term performance [8]-[10]. Based on this positive linkage between market orientation and institutional sustainable financial performance in various industries, this study emphasizes on the role of market orientation for achieving high performance by microfinance providers. In addition, two control variables namely, having sustainable customers and employees are considered as factors that may affect on the relationship between dimensions of market orientation and financial sustainability. Hence the current study posits market orientation of a firm as an independent variable and sustainable financial performance, (Adjusted Return on
Assets (ROA), and financial self-sufficiency) as the dependent variable.

According to previous studies, it is expected that following market orientation's strategies assists organizations to reach superior social and financial performance. This argument is fully supported by stakeholder theory as well as some Islamic concepts such as "Brotherhood" and "Al-adl". To [11] and [12], using market orientation strategies in order to create superior value for customers, supporting customer failures, adherence to social responsibilities and paying attention to get Allah's satisfaction more than financial benefit, can help IMFs to attract more customers and stay sustainable, socially and financially.

As mentioned above, market orientation has three dimensions: customer orientation, competitor orientation and inter-function coordination. Customer orientation means driving corporations based on the current and future needs of customers. A study by [13], found that firms can improve profits from $25 \%$ to $85 \%$ by making an improvement of only $5 \%$ in their customer retention. Furthermore, they have found that if 2-5 percent of the additional customers are retained, it has the same effect as cutting costs by $10 \%$ which will increase the profit. Thus, this study hypothesizes that:

H1: Customer orientation has a positive and significant impact on sustainable financial performance of microfinance institutions.

The second characteristic of market-oriented organizations is competitor orientation. By definition, competitor oriented organizations monitor and analyze the actions and capabilities of competitors for making just in time decisions in order to show the best reactions [8]. A competitor-oriented organization firstly should be informed about the level of competitive intensity by knowing the competitive environment. It should be able to evaluate its own ability and power as well as that of its competitors. This organization should have a systematic procedure for gathering and transferring information from the competitors to top management for making suitable and just in time decisions [14], [4]. Hence, the current study hypothesizes that:

H2: Competitor orientation has a positive and significant impact on sustainable financial performance of microfinance institutions.

Inter-function coordination is reflecting level of interactions and communications that assists organization to provide better quality of services [15]. Generally, market-oriented organizations should have something new for presenting such as innovations to impress the market and customers in order to persuade them to stand by the organization. Inter-function coordination is directly related to the top management attitude of whether they want to be the best in the market or otherwise. If so, how much is their risk tolerance? Alternatively, do they have the capability for being innovative? [16]. Thus, the following hypothesizes is considered:

H3: Inter-function coordination has a positive and significant impact on sustainable financial performance of microfinance institutions.

\section{Methodology}

The current study empirically tests the level of influences 
of three dimensions of market orientation as independent variables on financial performance of AIM, similar to the approach used by [8]. For measuring the level of a firm's market orientation, the 14 items MKTOR scale developed by [8] and the 32-item scale of market orientation originally developed by [9] and [17] were used. This part of consists three items for measuring customer orientation inclusive of 19 questions (Analyzing customer's current and future demands, Creating superior customer value and Identifying Customer target market), four items for measuring competitor orientation through 14 questions (Competitive intensity, Gathering data, Sharing and analyzing data and Responsiveness). Further, four items for inter-function coordination inclusive of 19 questions (Top managers Emphasis, Top management Risk Tolerance, Interdepartmental Conflict and Interdepartmental Connectedness). Similarly, top managers of AIM responded to the measurements of financial sustainable performance according to [18], (Profitability, Liquidity and Efficiency).

Finally, the control variables, sustainability of customers and employees were addressed. Although the primary focus of this study is on examining the linkage between dimensions of market orientation and accountability in financial sustainability of AIM, there are several other organizational factors which may affect organizational accountability in sustainability. Such factors have been considered as control variables in studies on market orientation, like [19]-[21], they include sustainability of customers and employees. In other words, these two control variables may determine the effects of the independent variables on the dependent variables and influence the relationship between them. Questions relating to customers and employees sustainability include customer's/employee's satisfaction level and whether this organization has got old customers/employees. A seven-point scale anchored by "strongly disagree" and "strongly agree" was used in the current study.

Questionnaire protocol was used as the primary means for data collection. Data were gathered from three distributed types of questionnaires. First category of questionnaires was distributed among AIM's top management level. In this particular category, all respondents were decision makers and have influences on the organization's strategies. These managers responded to measurements related to the independent variables (three dimensions of market orientation) and dependent variables (measurements of organization's sustainability). Data was collected from 30 respondents out of 45 questionnaires that constitute $75 \%$ of AIM's top management level at the monthly centre meeting in the main branch.

The second and third types of questionnaires were distributed among employees and customers for getting data about the sustainability of employees and customers in AIM, respectively. For these last two respondent categories, six branches were chosen randomly out of 41 active branches in three states; Perak, Pahang and Selangor (states those were holding regular weekly centre meeting during data collection period). Two branches were chosen in each selected states, one branch with more than 5000 customers and another one with less than 5000 customers. The questionnaires were distributed and collected during the branches' weekly centre meeting. In total, 400 customers and 300 employees responded to the related questionnaires which according to [22] are reliable.

The current study used Partial Least Squares (PLS) through Smart PLS software for testing the hypothesis of the study. According to [23], in order to achieve much more accurate results, when sample size is small and different numbers of respondents are used, applying variance based Structure Equation Modeling (SEM), meaning Partial Least Squares (PLS) is highly recommended.

\section{RESUlTS AND DiscUSSION}

All indices presented in Table I such as paths weights and the bootstrap critical ratios respectively exceed the cut off points (paths coefficient greater than 0.2 and critical ratios greater than $1.96 ; p<0.05)[24]$.

TABLE I: PARTIAL LEAST SQUARES RESULTS FOR THE CONCEPTUAL MODEL

\begin{tabular}{llllc}
\hline \hline $\begin{array}{l}\text { Predicted } \\
\text { variable }\end{array}$ & $\begin{array}{l}\text { Predictor } \\
\text { variable }\end{array}$ & Hypothesis & Path & Critical ratio \\
\hline $\begin{array}{l}\text { Customer } \\
\text { Orientation } \\
\text { Competitor }\end{array}$ & $\begin{array}{l}\text { Financial } \\
\text { sustainability }\end{array}$ & H1 & $0.452 *$ & 7.01 \\
$\begin{array}{l}\text { Frinancial } \\
\text { sustainabilion }\end{array}$ & H2 & -0.16 & 0.89 \\
$\begin{array}{l}\text { snter-function } \\
\text { Coordination }\end{array}$ & $\begin{array}{l}\text { Financial } \\
\text { sustainability }\end{array}$ & H3 & $0.23^{*}$ & 2.7 \\
\hline \hline
\end{tabular}

Note: *Path is significant

Based on the results in Table I, financial sustainability of AIM is highly affected by customer orientation. AIM has got high ability in providing new services based on the clients' preferences and their future demands by analyzing their current needs. Totally, fully adoptable to the customer orientation definition, AIM places the clients (as its main financial resources) at the center of all the activities and provided services. So, as it was expected the first hypothesis is fully supported.

However, the results have shown that there is a conflicting theoretical perspective in the competitor orientation part. Nevertheless, because of non-competitive market in the microfinance business in Malaysia, competitor orientation does not affect financial sustainability of AIM significantly, however according to previous studies, it is revealed that in normal markets (with more competitive atmosphere), financial sustainability of organizations could be affected by competitor orientation (Armstrong \& Collopy, 1996; Jaworski \& Kohli, 1993). Thus, the second hypothesis is not supported.

On the other hand, the results proved inter-function coordination also influence the financial sustainability of AIM, significantly. AIM's top management has got acceptable level of inter-organizational interactions and communications which is leading AIM to be a united and integrated organization. What more, AIM is using to consult with experts in different aspects such as shariah. For instance they got shariah panel as internal and Bank Islam as external shariah advisors. These valuable characteristics assist AIM's decision maker level to be more innovators and affect the market by providing new services with the lowest possible risk. So, the third hypothesis is also supported. 


\section{CONCLUSion AND Future RESEARCH}

This empirical study advances past theories such as the stakeholder theory, or marketing-based theories like adaptive structuration theory and agency theory, about market orientation and organizational accountability in financial sustainability. From both theoretical and empirical standpoints, the current study attempted to address the gap in the "financial sustainability market orientation research" in microfinance business; employing accountability at the micro level such as sustainability of management and financial performance. In addition, the results also indicated there is a conflicting theoretical perspective on the nature of market orientation (dimensions of market orientation). This study addressed this gap by empirically determining:

- The effects of each dimension of market orientation on both management sustainability and financial performance sustainability; and

- The effects of two major control variables (sustainability of customers and employees) on sustainable management and financial sustainable performance (simultaneously with dimensions of market orientation).

To sum up, the current study provided some empirical evidences that following customer orientation and inter-function coordination influence accountability in sustainability of management and financial sustainability of AIM, significantly. However, competitor orientation has negative and insignificant impacts on sustainability of AIM. Although, AIM is the biggest microfinance provider in Malaysia, but nowadays microfinance business in Malaysian banking industry are becoming very popular and serious competitors are coming. So, AIM can increase its social and financial performance by enhancing its ability in terms of analyzing the competitor's actions to save their current clients. Even more, improving customer orientation and Inter-function coordination also still recommended.

As far as future research is concerned, several additional research areas can be suggested. Particularly promising is the investigation of the relative combinations of various organizational behaviors and attitudes on sustainability or investigation on influences of market orientation on other characteristics of a successful organization, like efficiency and profitability. Even more, comparing level of being market oriented between two (or more) organizations or two (or more) different markets is also suggested. This configurationally approach would provide additional insights into the relative value of other organizational actions by generating a bigger picture of the potential impact of managerial decision making and organizational characteristics on.

\section{REFERENCES}

[1] P. J. Li and R. How, "Microfinance in Malaysia," in Malaysian Economic Development, H. W. Mun Ed., Malaysia: Malaysian Economics Development, 2007, pp. 133-143.

[2] M. Ramli. (2001). Amanah Ikhtiar Malaysia: The Oldest GB Replication. [Online]. Available:
[ http://www.grameen-info.org/dialogue/dialogue47/crMalaysia.html

[3] I. Ahmad, Current Situation of Microfinance in Malaysia and Its Issues, Kuala Lumpur, Malaysia: Agriculture Bank of Malaysia, 2003.

[4] A. K. Kohli and B. J. Jaworski, "Market orientation: The construct, research propositions and managerial implications," Joumal of Marketing, vol. 54, pp. 1-18, 1990.
[5] N. Nawai and M. S. Bashir, Evaluation of Micro Credit Program for Poverty Alleviation: A Case of Amanah Ikhtiar Malaysia (AIM), 2009.

[6] N. M. Saad, "Microfinance and prospect for Islamic microfinance products: The case of Amanah Ikhtiar Malaysia," Advances in Asian Social Science, vol. 1, no. 1, pp. 27-33, 2012.

[7] S. N. Bhuian, "Exploring market orientation in banks: an empirical examination in Saudi Arabia," Journal of Services Marketing, vol. 11, no. 5, pp. 317-328, 1997.

[8] J. C. Narver and S. F. Slater, "The effect of a market orientation on business profitability," The Journal of Marketing, pp. 20-35, 1990.

[9] B. Jaworski and A. Kohli, "Market orientation: Antecedents and consequences," Journal of Marketing, vol. 57, pp. 53-70, July 1993.

[10] R. W. Ruekert, "Developing a market orientation: An organizational strategy perspective," International Journal of Research in Marketing, vol. 9, no. 3, pp. 225-245, 1992.

[11] R. E. Freeman, A Stakeholder Theory of Modern Corporations Ethical Theory and Business, 7th ed. 2004.

[12] M. A. E. Gamal, "Introduction to Islamic finance," Handbook of Finance, 2008.

[13] F. F Reichheld and W. E. Sasser, "Zero defections quality comes to services,"Harvard Business Review, vol. 68, no. 5, pp. 105-111, 1990.

[14] S. Armstrong and F. Collopy, "Competitor orientation: Effects of objectives and information on managerial decisions and profitability," Journal of Marketing Research, pp. 385-394, 1996.

[15] A. Grinstein, "The effect of market orientation and its components on innovation consequences: A meta-analysis," Journal of the Academy of Marketing Sciece, pp. 166-173, 2008.

[16] G. Gresham, J. Hafer, and E. Markowski, "Inter-functional market orientation between marketing departments and technical departments in the management of the new product development," Institute of Behavioral and Applied Management, pp. 43-65, 2006.

[17] S. N. Bhuian and M. Habib, "The relationship between entrepreneurship, market orientation and performance: A test in Saudi Arabia," Journal of Transnational Management, vol. 10, no. 1, pp. 79-98, 2005.

[18] P. León, Four Pillars of Financial Sustainability: Nature Conservancy, 2001.

[19] S. P. Sebhatu, Sustainability Performance Measurement for Sustainable Organizations: Beyond Compliance and Reporting, Karlstad, Sweden, 2009.

[20] Y. P. Acharya and U. Acharya, "Sustainability of microfinance institutions from small farmers' perspective: A case of rural Nepal," International Review of Business Research Papers, vol. 2, no. 2, pp. 117-126, 2006.

[21] V. L. Crittenden, W. F. Crittenden, L. K. Ferrell, O. C. Ferrell, and C. C. Pinney, "Market-oriented sustainability: a conceptual framework and propositions," Journal of the Academy of Marketing Science, vol. 39, no. 1, pp. 71-85, 2011.

[22] G. D. Israel, Determining Sample Size: University of Florida Cooperative Extension Service, Institute of Food and Agriculture Sciences, EDIS, 1992.

[23] M. Haenlein and A. M. Kaplan, "A beginner's guide to partial least squares analysis," Understanding Statistics, vol. 3, no. 4, pp. 283-297, 2004.

[24] R. F. Falk and N. B. Miller, A Primer for Soft Modeling, University of Akron Press, 1992.

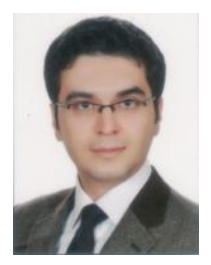

Soheil Kazemian was born in Shirvan, Khorasan, Iran, on September 21, 1985. He got the bachelor science in accounting at 2007 from Fredowsi University of Mashhad (FUM), Iran. Further, he successfully finished the master of science in Accounting at 2010 in Islamic Azad University of Tehran, Sciences \& Research branch, Iran. Now, he studies Ph.D. of accountancy since 2011 in Universiti Teknologi Mara (UiTM), Shah Alam, and

Malaysia.

He was working as an accountant and then the head of Accounting Department of "Sepehr Andishan Sanabad" Civil Engineering Company since 2009 to 2011 in Mashhad, Iran. In addition he was a part time lecturer in some universities in Iran like: "Islamic Azad University of Daregaz, Daregaz, Khorasan, Iran", "Kavian Institute of Higher Education, Mashhad, Iran", "Jahad daneshgahi, Mashhad, Iran", "Science \& Application University, Chenaran, Iran".

Mr. Kazemian also won silver medal at at IIDEX 2013 "invention, innovation, design \& expo 2013" for his project namely, "Sustainable Market Oriented Islamic microfinance Institutions Model". 